\title{
ARCHITECTING THE ENTERPRISE TOWARDS ENHANCED INNOVATION CAPABILITY
}

\author{
L. Louw ${ }^{1 *}$, H.E. Essmann ${ }^{2}$, N.D. du Preez ${ }^{1} \&$ C.S.L. Schutte ${ }^{1}$
}

\section{ARTICLE INFO}

\section{Article details}

Submitted by authors 2 Sep 2016

Accepted for publication 16 Aug 2017

Available online

13 Dec 2017

Contact details

Corresponding author

louisl@sun.ac.za

Author affiliations

1 Department of Industrial

Engineering, Stellenbosch

University, South Africa

2 Devil's Peak Brewing Company, South Africa

\section{DOI}

http://dx.doi.org/10.7166/28-4-1628
In today's competitive environment, organisations cannot afford to focus only on effectiveness and efficiencies - they also need to innovate. This is evident from most literature sources on innovation. Innovation topics, such as the innovation process and the drivers, barriers, principles, and success factors for innovation, have received a lot of attention in the literature. What is still lacking, however, is a consolidated view of the core requirements for building an innovation capability within an organisation. This paper lays the foundation for an innovation capability reference architecture by identifying those innovation success factors or requirements described in the literature, and consolidating and structuring it within an easy-to-use enterprise architecture framework.

\section{OPSOMMING}

Die meeste literatuurbronne wat handel oor innovasie stem saam dat in vandag se mededingende omgewing ondernemings nie kan bekostig om net op doeltreffendheid en effektiwiteit te fokus nie hulle moet ook innoveer. Innovasieonderwerpe soos die innovasieproses, sowel as die drywers, struikelblokke, beginsels en suksesfaktore vir innovasie geniet ook heelwat aandag in die literatuur. Daar ontbreek egter nog steeds 'n gekonsolideerde oorsig van die kern vereistes vir die ontwikkeling van ' $n$ innovasie vermoë in ondernemings. Hierdie artikel lê die grondslag vir 'n innovasievermoë verwysingsargitektuur deur die innovasie suksesfaktore of vereistes soos bespreek in die literatuur te identifiseer, en dan te konsolideer en te struktureer in 'n maklik bruikbare ondernemingsverwysingsargitektuur.

For many organisations efficiency, effectiveness, productivity, and quality are still the preferred ways to improve the organisation. However, in today's competitive environment, organisations cannot afford to focus only on effectiveness and efficiencies (improving their current business) they also need to innovate in order to create their future business and so ensure longer-term prosperity [88], [30], [61], [4].

According to Geoffrey Moore [61], enterprises need to evolve continuously; and this evolution should be driven by innovation. Moore [61] states: "To innovate forever, in other words, is not an aspiration; it is a design specification. It is not a strategy; it is a requirement". This requires that innovation become part of an organisation's way of doing things; it must develop a fundamental capability to innovate.

Many studies in the literature attempt to develop the concept of innovation capability [62], [63], [8], [92], [41], [101], [98], [39], [6]. These capabilities mainly reside within the organisation's strategies, processes, values, knowledge and competencies, and people [100], [62], [25]. 
Although the literarure agrees on the processes, drivers, barriers, and requirements for innovation [23], [29], [89], [17], [88], [40], the field of innovation capability is still opaque, and lacks consolidation about the core requirements for building an innovation capability within an organisation [101], [87], [14]. Also lacking are generic design principles for guiding enterprise engineers in designing or re-designing (architecting) organisations towards an enhanced organisational capability for innovation.

This paper aims to lay the foundation for an innovation capability reference architecture by identifying those requirements and practices described in the literature as conducive to innovation, and to structure it within an easy-to-use enterprise architecture framework. This framework with innovation capability requirements can be used in follow-up studies to develop generic design principles for building innovative organisations. This will greatly assist enterprise architects/engineers and managers in building more innovation-capable organisations.

The paper begins by exploring the concepts and definitions for innovation capability described in the literature. This is followed by a thorough structured review of the literature in order to identify the organisational characteristics and requirements that are conducive to developing an innovation capability. For this analysis, a content analysis approach called Latent Dirichlet allocation (or LDA) - an electronic topic modelling analysis approach - was used. Using this approach, the core organisational innovation capabilities that are described in the literature were researched and then summarised and categorsed within a three-dimensional innovation capability maturity framework that has been developed. The final consolidated innovation capability requirements extracted from the literature and organised in this innovation capability maturity framework were then mapped and captured within an enterprise architecture framework in order to provide the basis for further development of enterprise design principles for designing more innovation-capable organisations.

\section{INNOVATION CAPABILITY}

Hamel [44] defines innovation capability as the assembling of the "right ingredients" for innovation in an organisation. The notion and importance of innovation capabilities is also described by Assink [8], who states: "Developing distinct capabilities ... should be an integral part of a company's strategy for growth". Assink [8] also highlights "the key role of strategic management in appropriately adapting, integrating and reconfiguring organisational skills, resources and functional competencies to match the requirements of a changing environment".

Neely et al. [62] and O'Connor and Ayers [63] define innovation capability as the potential of an organisation to innovate. Ahmed [2] distinguishes between "hard" and "soft" innovation capabilities. Hard innovation capabilities include physical, tangible, and/or measurable aspects such as innovation structures, processes, procedures, physical infrastructure, metrics, and resources that enhance innovation output. Soft innovation capabilities deal with less tangible and measurable aspects such as culture, climate, and leadership conducive to innovation.

Lawson and Samson [52] highlight the importance of operating the current business while at the same time creating the future business, and define innovation capability in these terms:

"the ability to continuously transform knowledge and ideas into new products, processes and systems for the benefit of the firm and its stakeholders. Innovation capability is not just an ability to be successful at running a business newstream, or to manage mainstream capabilities. Innovation capability is about synthesising these two operating paradigms."

In order to compete through innovation, organisations therefore need to develop certain innovation capabilities that will increase their probability of success. Innovation capability in this paper is defined as "the organisational means with which innovative outputs may be facilitated" [38]. This, however, raises the question: What are those requirements and practices for developing an innovation-capable organisation?

The next section is a summary of innovation best practices extracted from the literature. This literature study was used to establish the generic factors that are associated with innovation capability, and that therefore contribute to the successful execution of innovation initiatives. 
According to the literature on innovation, a key innovation capability requirement is a well-defined innovation process. Such a process should cover all the stages of innovation, from the identification of ideas and opportunities, to the successful implementation, commercialisation, and/or exploitation of innovation [88], [25], [63], [8]. This process includes effective ways of developing or generating ideas, identifying opportunities, and linking ideas and opportunities and developing solutions for those opportunities [42], [2], [45], [88], [9], [63], [96]. Specific practices include scanning for opportunities that are both internal and external to the organisation [88], [9], [63], effectively generating and managing ideas [45], [63], [2], [62], [9], [73], challenging current convention and assumptions, and taking a new perspective on things [42], [26], [63], [96].

However, identifying opportunities with great potential and developing them into business alternatives requires effective management of the initial phases of innovation (also called the 'innovation front end') [21], [9], [73], [54], [94], [48]. Practices include identifying and addressing barriers to innovation initiatives [24], [25], managing uncertainties and risks [94], [48], testing and screening ideas, and prioritising opportunities [100], [2], [45], [88], [9], [25], [32], [61], [63], [48].

Innovation requires a lot of decision-making, but often with only limited information and time available. So being efficient and effective with knowledge is a critical requirement [19], [47], [69], [15], [45], [36], [80]. Thus identifying and facilitating knowledge processes is important [15], [60], [36]. Tools and techniques need to be identified for storing, structuring, and retrieving knowledge [36], [45]. Also important is the consideration of complementary knowledge areas and the ability to combine different knowledge components [22], [9], [36], [8]. Knowledge also needs to be disseminated throughout the organisation to enable it to be used [3], [68], [19], [45], [25], [32], [91]. Good practices include identifying groups with similar knowledge needs to enable knowledge exchange [68], [19], [25], [91], encouraging a trusting environment that is open to sharing and interaction [45], linking with external collaborators to provide new or different perspectives [19], [3], [32], structuring knowledge, and providing a common vocabulary to facilitate knowledge-sharing and knowledge-retrieval [19], [91].

The literature also highlights the importance of an innovation strategy in developing an innovation capability [44], [100], [3], [9], [25], [64]. Such an innovation strategy defines the impact, type, and level of innovation required, as well as the organisational structures needed to maximise the possibility of achieving these innovations. The innovation strategy needs to be communicated or shared throughout the organisation, so that the strategic intent is clear to everyone in it [2], [25], [64], [91].

A climate and culture conducive to innovation also plays a critical role [49], [100], [78], [2], [3], [16], [45], [25]. Individuals need to be encouraged to take risks and to challenge the norm, learn from failures, and be proactive and creative [3], [25]. Management should therefore motivate employees to experiment - and, if they fail, to accept such failure as part of the learning experience [3].

Leadership plays an important role in creating a climate and culture conducive to innovation. The need to support and encourage innovative behaviour, demonstrate commitment towards innovation, acknowledge the important role of people in innovation, and develop, support, and encourage innovation champions within the organisation [2], [49], [74], [100], [3], [62], [25], [48], [50].

An efficient organisational structure for supporting or enabling innovation is also important. The literature indicates that decentralised decision-making authority and flexible, flat, and transparent organisational structures are conducive to innovative outputs [49], [28], [100], [2], [3], [16], [43], [9], [25], [91].

Organisational resources that are crucial to innovation should be identified, developed, aligned, and effectively managed [2], [3], [54], [91], [61], [45], [16]. The right individuals should be selected for the various innovation roles, while ensuring a diverse mix of skills and disciplines. Core organisational competencies also need to be identified, understood, and managed, and new competencies need to be developed [71], [42], [2], [16], [61]. 
Since innovation implies a change process, organisations need to develop the ability to adapt and change [100], [42], [16], [22], [9], [40], [48]. This requires developing an attitude that is receptive to change, that engages employees early in the change process, that understands the change process, and manages it pro-actively.

External involvement in the innovation process has also been identified in previous studies as an essential requirement for an improved innovation capability [74], [100], [2], [3], [13], [73], [25], [50]. This includes the involvement of clients, suppliers, partners, and other external stakeholders in various activities of the innovation process. Good practices include facilitating and enabling good communication with external stakeholders [74], [25], [50], building relationships with clients, suppliers, and partners [74], [3], interacting with clients in order to identify their needs, problems, and ideas, tapping into their explicit knowledge [2], [13], and using their requirements to drive initiatives.

Organisations also need to have a future orientation and take a longer-term view of opportunities [83], [5], [50], [73], [32], [70]. Good practices include both wide and deep scanning of different and related environments to identify opportunities [83], [73], [50], [32], identifying the future technology developments and timelines of such technologies (technology roadmapping) [50], and relating opportunities to core competencies and resources [83].

Diverse teams of individuals from different disciplines and functions in the organisation, with different skills sets, are seen to facilitate innovation [71], [100], [2], [3], [62], [97], [25], [32]. Individuals and teams should be encouraged to interact, collaborate, and share across organisational boundaries.

In summary, the above section has highlighted various requirements for enhancing innovative outputs in an organisation or enterprise. These requirements span various 'hard' organisational aspects such as structures, processes, procedures, infrastructure, metrics, resources, along with 'softer' aspects such as culture, climate, and leadership (entailing proper and effective management of the 'hard' aspects). For innovation to become embedded in an organisation's way of doing things, the principles of innovation must be applied not only to the organisation's products and processes, but also to its strategy. Innovation capabilities therefore need to be purposefully 'built into' the DNA of an enterprise; and this requires a structured engineering approach. The authors believe that the discipline of enterprise engineering provides the required frameworks, methodologies, and tools for designing, developing, and implementing such innovation capabilities into the DNA of an organisation or enterprise.

The next section provides some background on the discipline of enterprise engineering, which will be used at the end of the paper to introduce an enterprise architecture framework for organising the various innovation capability requirements that have been extracted and consolidated from the literature. This architectural framework can in turn be used to develop innovation capability design principles that will guide and steer the design and development of an enterprise with an enhanced capability for innovation.

\section{ENTERPRISE ENGINEERING AND ENTERPRISE ARCHITECTURES}

Enterprise engineering is a discipline with a life-cycle and systems view of an organisation. It views the enterprise as a complex, integrated system that can be purposefully designed or re-designed [31], [90], [10]. It applies "systems theory and engineering techniques to the specification, analysis, design, and implementation of an enterprise for its life cycle" [75].

Liles et al. [55] define enterprise engineering as

"that body of knowledge, principles, and practices having to do with the analysis, design, implementation and operation of an enterprise. In a continually changing and unpredictable competitive environment, the Enterprise Engineer addresses a fundamental question: how to design and improve all elements associated with the total enterprise through the use of engineering and analysis methods and tools to more effectively achieve its goals and objectives."

Martin [58] describes enterprise engineering as "an integrated set of disciplines for building or changing an enterprise, its processes, and systems". 
Rebovich [72] defines enterprise engineering as an emerging discipline "for developing enterprise capabilities". It is a multi disciplinary approach that "takes a broad perspective in synthesizing technical and non-technical aspects of enterprise capability".

Because multiple disciplines have to be integrated as a whole within the complete enterprise system, enterprise design or re-design is not a simple task. Weinberg [93] describes enterprises as organised complexities that are therefore highly complex and highly organised. This combination of complexity and organisation makes it difficult to use analytical or statistical approaches for problem-solving. Dietz et al. [31] therefore highlight the importance of design principles that will guide the (re)design of an enterprise. According to Dietz et al. [31], to "ensure that an enterprise operates in a unified and integrated manner, and in compliance with its strategic intentions and areas of concern, the development process of enterprises and of their supporting systems must be controlled by functional and constructional design principles, in addition to the applicable specific functional and constructional requirements". They define architecture as "a coherent, consistent, and hierarchically ordered set of such principles". The collective architectures of an enterprise at any moment are called the enterprise architecture at that moment [31].

Enterprise architecture is an important concept within the enterprise engineering discipline. It dates back to the mid-1980s when Zachman developed the Zachman framework - a reference framework focused on designing and improving the information architecture of an enterprise.

Since Zachman, various other enterprise architecture frameworks and definitions have been developed. Some of these definitions are described below.

- The Institute of Electrical and Electronics Engineers (IEEE) defines architecture as: “...the fundamental organization of a system embodied in its components, their relationships to each other, and to the environment, and the principles guiding its design and evolution" [57].

- The Open Group's Architectural Framework (TOGAF) notes that "Architecture has two meanings depending upon its contextual usage: (1) A formal description of a system, or a detailed plan of the system at component level to guide its implementation; (2) The structure of components, their interrelationships, and the principles and guidelines governing their design and evolution over time".

- "EA (Enterprise Architecture) is a coherent set of principles, methods and models used in the design of an enterprise's organisational structure, business processes, information systems and infrastructure" [51].

Op't Land et al. [65] provide a concise summary of the various enterprise architecture definitions: "While the various definitions for enterprise architecture may seem to differ considerably, what all these definitions seem to have in common is a reference to structure and relationships combined with a reference to a set of governing principles that provide guidance and support for directions and decisions. Enterprise architecture focuses on shaping and governing the design of the future enterprise using principles to stipulate future direction and models to underpin and visualize future states."

Imperative in the design or re-design of an enterprise is the development of an understanding of both the current and the required architecture of an enterprise. This implies understanding the different enterprise components, how they operate or function, and the relationships between components. Enterprise architectures all aim to facilitate enterprise engineering and integration by providing frameworks, principles, and models that can be used to analyse and design the enterprise. They can thus be seen as metamodels of the enterprise that contain the contextual information required to design or re-design an enterprise [56].

\section{CONSOLIDATION AND STRUCTURING OF INNOVATION CAPABILITY REQUIREMENTS WITHIN AN ENTERPRISE ARCHITECTURE FRAMEWORK}

\subsection{Approach to consolidating innovation capability requirements}

The innovation capability literature corpus collected as part of this study, and described briefly in section 3, was reviewed and analysed using a combined manual and electronic topic modelling analysis approach, using Latent Dirichlet Allocation (LDA). The goal was to identify, summarise, and 
categorise the core organisational innovation capabilities that were researched and described in the literature. (For a more detailed discussion of the LDA technique, refer to Blei et al. [11].)

The manual analysis process involved reviewing, in detail, the contents of the innovation capability corpus identified within the literature in order to identify those core organisational innovation capabilities described in previous research studies. Capabilities described by several and recognised sources were used as validation. This produced an initial set of generic innovation best practices from the literature. The results were presented in a table capturing all the metadata on the documents (author(s), keywords, etc.), and the various themes of innovation capability identified in each. This table was then used in the final consolidation process. Publication constraints mean that this table cannot be presented in this paper; for its details, refer to Essmann [38].

After the manual analysis, an electronic topic modelling analysis was conducted, using the LDA topic modelling approach. This provides an objective view of the innovation capability corpus. LDA is a generative probabilistic model for collections of discrete data [11]. The distribution of words in the corpus is derived through statistical analysis, which is used to identify topics in the corpus. Documents are then represented as random mixtures over latent topics [11]. LDA therefore helps to identify structure in text that is unstructured [12].

The LDA-based topic modelling approach was used, therefore:

1. To identify the core concepts (or topics) pertaining to innovation capability according to the LDA-based topic modelling process.

2. To depict the (text-based statistical) interrelations between the topics of innovation capability.

3. To identify hierarchical structure within the topics of innovation capability.

The results from the manual interpretation and the LDA topic modelling analysis were then consolidated and refined to derive a final list of innovation capability requirements.

The identified innovation capability requirements were then structured within a three-dimensional framework consisting of different innovation constructs on the $y$-axis, organisational constructs on the $x$-axis, and innovation capability maturity levels on the z-axis (Figure 1) [37].

The innovation capability construct on the $y$-axis uses two levels of detail to describe organisational innovation capability. The highest level components are referred to as 'innovation capability areas' (such as 'innovation process' and 'knowledge \& competency'). The second level components are referred to as 'innovation capability construct' Items (such as 'innovation strategy \& leadership'). These capability areas imply three fundamental areas of innovation capability that can be defined:

1. Innovation process: the practices, procedures, activities, etc. that take ideas and/or opportunities through to concepts, then through development and implementation, and eventually to a stage of commercialisation and operation (which may include continuous refinement and optimisation). Basically, it refers to the complete innovation lifecycle.

2. Knowledge \& competency: the innovation process requires both specific and broad-based knowledge and competency, whether already within the organisation or still to be developed or acquired. Also included are the associated management requirements for knowledge, competencies, and technology.

3. Organisational support: the structures, resources, measures, infrastructure, strategy, policies, leadership, etc. that are needed to support the process and the knowledge and competency requirements for innovation.

The 'organisational construct' defined on the x-axis of the framework ensures that the fundamental aspects of an organisation are addressed by the content of the model. Furthermore, describing the innovation capability and organisational constructs in a matrix makes it possible to depict the interrelations and impact between the capability requirements and the organisational attributes. 


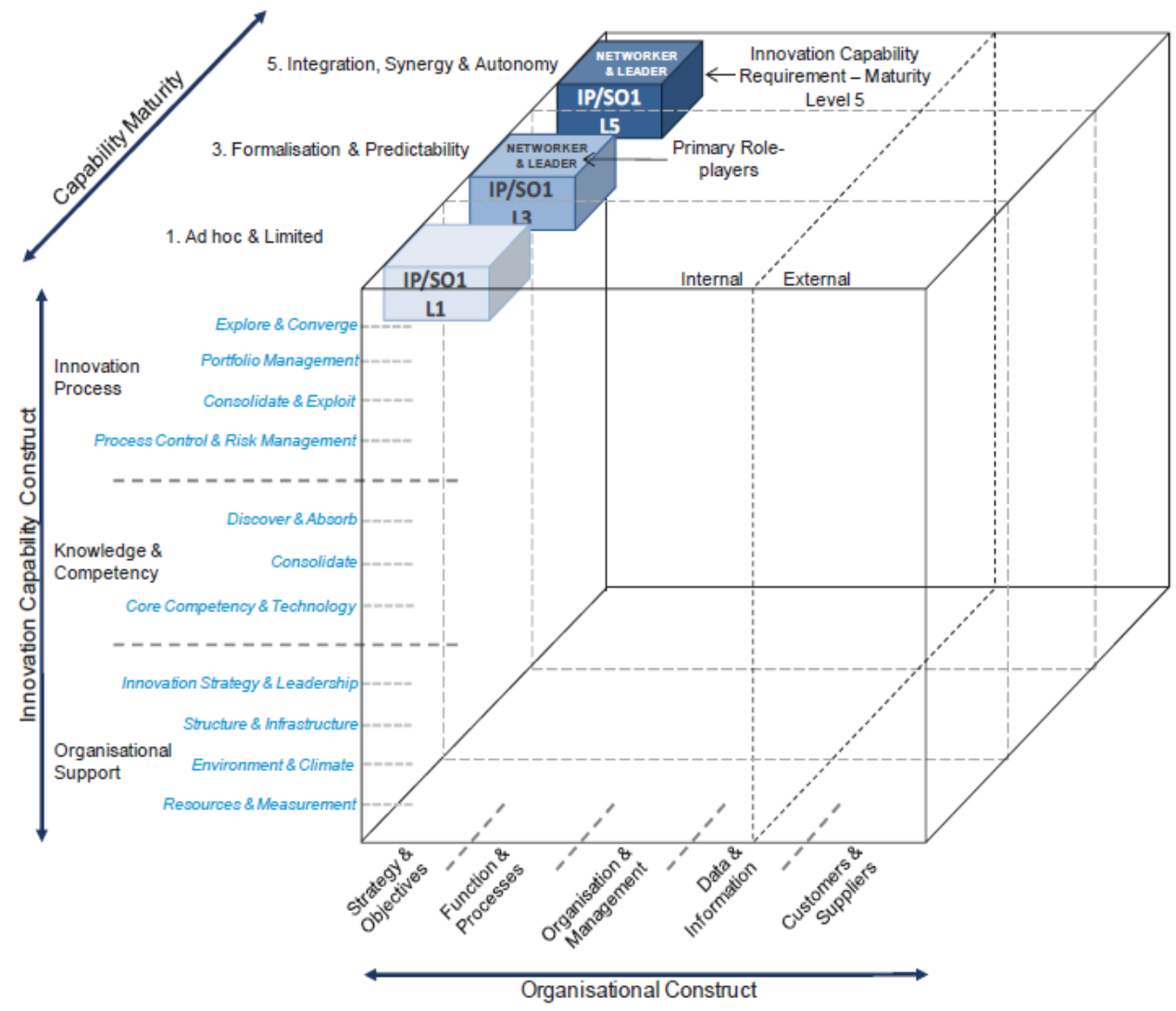

Figure 1: Innovation capability maturity framework

\subsection{Selecting and organising the innovation requirements within an enterprise framework}

In order for the innovation capability requirements to be used in the design and re-design of enterprises, the need was identified to map and structure these requirements within a framework describing the architecture of a generic enterprise. Various enterprise architecture models are described in the literature. Amongst the most well-known are the computer integrated manufacturing open system architecture (CIMOSA) [7], the Purdue enterprise-reference architecture (PERA) [95], the GRAl integrated methodology (GIM) architecture [35], GERAM [46], the Zachman framework [81], the Open Group architecture framework (TOGAF) [66], the Department of Defence architecture framework (DoD AF) [33], enterprise architecture planning (EAP) [82], integrated architecture framework (IAF) [77], and the federal enterprise architecture framework (FEAF) [18].

A comprehensive and useful enterprise architecture framework is the adaptive reference model ${ }^{\mathrm{TM}}$ developed by Adaptive Inc. [1].

This framework was slightly modified by the authors, and is presented in Figure 2. This modified framework consists of the following generic sub-architectures within an enterprise architecture:

- The strategic intent architecture: this describes the strategies for the enterprise that provides direction, and sets targets for the different enterprise processes and resources.

- The value chain \& process architecture: this covers the primary value chain along with management functions and processes. It describes the process in terms of inputs, outputs, governance, and enablers, and tracks the timing and life-cycles of primary business objects.

- $\quad$ The product/service architecture: this describes the different products and services offered by the enterprise, and how these deliver value to the customer or client.

- The organisation architecture is the formal organisational structure, as defined by management in pursuit of the strategic intent. 
- $\quad$ The governance architecture strives to create a sense of predictability and accountability by stipulating different types of governances, such as legislation, laws policy, guidelines, standards, and best practices.

- The performance architecture is a collection of process and resource measurements and measurement types as defined by strategic intent.

- $\quad$ The financial architecture describes the revenue, cost of sales, and expenses.

- The information and knowledge architecture reflects the blueprint of information and knowledge about applications, information, platforms, and networks in the context of the business process it supports.

- The human resources architecture is concerned with the optimum staffing and use of skill sets within the organisation.

- $\quad$ The physical asset architecture tracks physical assets and maximises their use.

The enterprise architecture, with its sub-architectures, is impacted by various external influences such as competitors, technological change, legislation and regulations, and the socio-economic environment. It also interacts with external suppliers, clients/customers, and alliances and partners. All of these external interactions are important considerations when designing or re-designing the enterprise architecture.

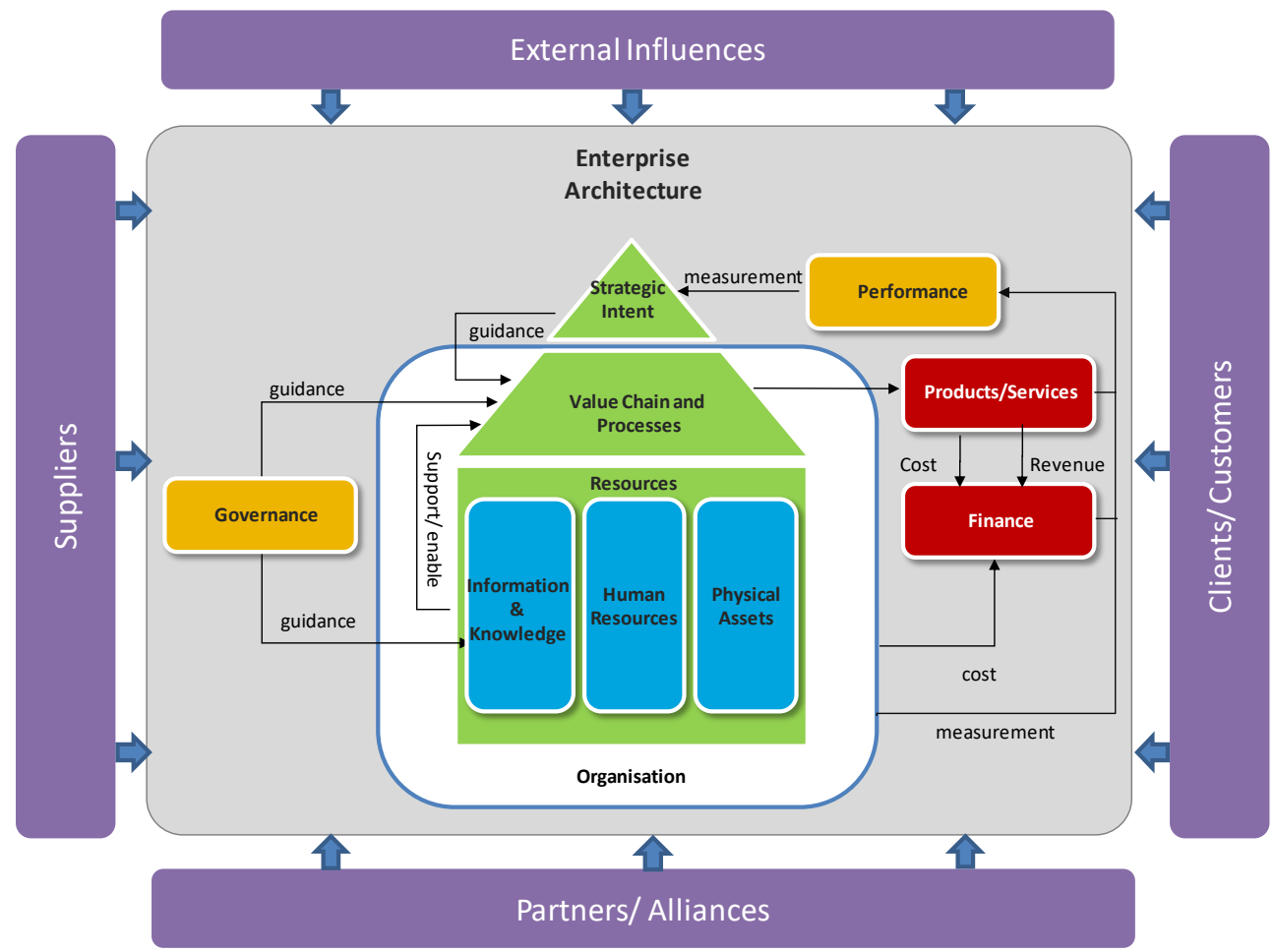

Figure 2: Enterprise architecture framework (modified from Adaptive's enterprise model)

Among the various enterprise architecture frameworks available in the literature, this architecture framework was selected for the following reasons:

- The simplicity of the framework: it is easy to understand and apply.

- The comprehensiveness of the framework: it incorporates the different sub-architectures and therefore the different views within an enterprise.

- It incorporates the business model view of an enterprise, which describes the design or architecture of the value creation, delivery, and capture mechanisms an enterprise employs [85], [67].

This architecture framework described was then used to structure and map the innovation capability requirements, as extracted from the literature, against the different sub-architectures within a generic enterprise. This was useful for two reasons: 
1. Ensuring the comprehensiveness of the capability requirements. By mapping the identified innovation capability requirements collected from the literature against the various enterprise sub-architectures, it could be evaluated whether the capability requirements adequately covers the different architectural elements of an enterprise. It therefore indicates whether the core requirements for innovation capability were aligned with the fundamental aspects of the organisation, thus ensuring the elimination of content-related gaps and overlaps.

2. Structuring the innovation capability requirements, based on the different enterprise subarchitectures, enables the development of design principles tyo guide the design of the various enterprise sub-architectures, thereby creating an enterprise architecture and subarchitectures that are capable of sustainable innovation.

The final consolidated innovation capability requirements, as extracted from the literature and organised within an enterprise architecture framework, are presented in Table 1.

Table 1: Innovation capability requirements structured within an enterprise architecture framework

\begin{tabular}{|c|c|}
\hline $\begin{array}{l}\text { Related enterprise sub- } \\
\text { architecture }\end{array}$ & $\begin{array}{l}\text { Consolidated innovation capability requirements from the } \\
\text { literature }\end{array}$ \\
\hline \multirow[t]{3}{*}{ Strategic intent architecture } & $\begin{array}{l}\text { Establishing a knowledge, competency, \& technology development \& } \\
\text { acquisition strategy. }\end{array}$ \\
\hline & $\begin{array}{l}\text { Developing \& conveying / communicating an innovation strategy \& } \\
\text { objectives. }\end{array}$ \\
\hline & $\begin{array}{l}\text { Defining an innovation model with associated processes, practices, } \\
\text { tools, etc. }\end{array}$ \\
\hline \multirow[t]{16}{*}{ Value chain \&process architecture } & $\begin{array}{l}\text { Involving customers at various stages throughout the innovation } \\
\text { process. }\end{array}$ \\
\hline & $\begin{array}{l}\text { Involving suppliers at various stages throughout the innovation } \\
\text { process. }\end{array}$ \\
\hline & Procedures for developing and elaborating concepts. \\
\hline & $\begin{array}{l}\text { Using appropriate project management techniques for the type of } \\
\text { innovation (incremental vs radical, sustaining vs disruptive). }\end{array}$ \\
\hline & $\begin{array}{l}\text { Procedures for developing \& acquiring the required innovation } \\
\text { process competencies. }\end{array}$ \\
\hline & $\begin{array}{l}\text { Procedures for ensuring supplier competency \& technology supports } \\
\text { innovation requirements. }\end{array}$ \\
\hline & $\begin{array}{l}\text { Practices to network and facilitate collaboration with external } \\
\text { parties (formal \& informal external networking \& collaboration). }\end{array}$ \\
\hline & Procedures for periodically probing and understanding the market. \\
\hline & Pro-active initiatives for identifying opportunities. \\
\hline & Procedures to manage and substantiate ideas. \\
\hline & Testing, screening \& prioritising opportunities \& concepts. \\
\hline & Concepts are quickly made tangible in the form of prototypes. \\
\hline & $\begin{array}{l}\text { Focused practices and procedures for developing and implementing } \\
\text { concepts. }\end{array}$ \\
\hline & $\begin{array}{l}\text { Procedures to reduce project uncertainty and identify, manage, and } \\
\text { mitigate risk, }\end{array}$ \\
\hline & Practices for exploring existing and new fields of research. \\
\hline & $\begin{array}{l}\text { Practices to network and facilitate collaboration between internal } \\
\text { teams. }\end{array}$ \\
\hline
\end{tabular}




\begin{tabular}{|c|c|}
\hline $\begin{array}{l}\text { Related enterprise sub- } \\
\text { architecture }\end{array}$ & $\begin{array}{l}\text { Consolidated innovation capability requirements from the } \\
\text { literature }\end{array}$ \\
\hline & $\begin{array}{l}\text { Involving other stakeholders (partners, alliances, etc.) in the } \\
\text { innovation process. }\end{array}$ \\
\hline & Procedures for scanning \& exploring for latent opportunities. \\
\hline & $\begin{array}{l}\text { Opportunities and concepts are coordinated and viewed in context } \\
\text { with required technology, competencies, processes, systems, etc. }\end{array}$ \\
\hline & Managing and balancing the innovation portfolio. \\
\hline & Managing intellectual property. \\
\hline \multirow[t]{5}{*}{ Information architecture } & $\begin{array}{l}\text { Procedures and tools for identifying, summarising, highlighting, } \\
\text { and/or extracting relevant information. }\end{array}$ \\
\hline & $\begin{array}{l}\text { Procedures and frameworks for contextualising, categorising, and } \\
\text { capturing, and tools for storing and retrieving data and information. }\end{array}$ \\
\hline & $\begin{array}{l}\text { Core information competencies are identified, managed, and } \\
\text { maintained to ensure that innovation project and operational needs } \\
\text { are continuously fulfilled. }\end{array}$ \\
\hline & $\begin{array}{l}\text { Core information technologies, systems, and tools enabling } \\
\text { innovation processes are identified, managed, and maintained. }\end{array}$ \\
\hline & $\begin{array}{l}\text { Communication \& the flow of information - mechanisms and tools to } \\
\text { facilitate the flow of information have been identified and } \\
\text { implemented. }\end{array}$ \\
\hline \multirow[t]{9}{*}{ Human resources architecture } & $\begin{array}{l}\text { Allocating resources appropriately to innovation - based on } \\
\text { prioritisation, and in balance with operational requirements. } \\
\text { Resources appropriately dedicated to innovation are provided, } \\
\text { ensuring sufficient 'slack' for activities. Needs are continuously } \\
\text { monitored and gaps filled. }\end{array}$ \\
\hline & $\begin{array}{l}\text { Core innovation-related competencies are identified, acquired, } \\
\text { developed, managed, and maintained. }\end{array}$ \\
\hline & $\begin{array}{l}\text { Organisational values \& policies - values and policies create an } \\
\text { environment that encourages individuals to communicate openly and } \\
\text { bring ideas forward. Time is allocated for learning, exploring, and } \\
\text { building relationships. }\end{array}$ \\
\hline & Change management procedures have been defined and deployed. \\
\hline & Initiatives for motivating, rewarding, \& celebrating success. \\
\hline & $\begin{array}{l}\text { Procedures to hire the 'right' people with needed skills, and align } \\
\text { existing personnel's skills with their role. }\end{array}$ \\
\hline & Championing \& encouraging innovation. \\
\hline & Creating cross-functional \& multidisciplinary teams. \\
\hline & Managing tacit knowledge. \\
\hline \multirow[t]{3}{*}{ Physical asset architecture } & $\begin{array}{l}\text { Physical resources are allocated to the portfolio of projects, based } \\
\text { on prioritisation and in balance with operational requirements. }\end{array}$ \\
\hline & $\begin{array}{l}\text { Core physical technologies are identified, managed, and maintained } \\
\text { to ensure that project and operational needs are continuously } \\
\text { fulfilled. }\end{array}$ \\
\hline & $\begin{array}{l}\text { Procedures for proactively identifying, developing, and/or acquiring } \\
\text { required physical technologies. }\end{array}$ \\
\hline
\end{tabular}




\begin{tabular}{|c|c|}
\hline $\begin{array}{l}\text { Related enterprise sub- } \\
\text { architecture }\end{array}$ & $\begin{array}{l}\text { Consolidated innovation capability requirements from the } \\
\text { literature }\end{array}$ \\
\hline \multirow[t]{3}{*}{ Organisation architecture } & $\begin{array}{l}\text { Flexible organisational structures that allow sharing/moving people } \\
\text { between projects and functions. }\end{array}$ \\
\hline & $\begin{array}{l}\text { Organisational structures are designed to ensure a networked } \\
\text { relation between entities (departments, teams, and individuals) that } \\
\text { stimulate communication and interaction. }\end{array}$ \\
\hline & The organisational structure enables quick decision-making. \\
\hline \multirow[t]{2}{*}{ Performance architecture } & $\begin{array}{l}\text { Innovation metrics have been identified, defined, and implemented. } \\
\text { Targets are aligned with innovation objectives. Metrics are } \\
\text { monitored to identify process and management improvements. }\end{array}$ \\
\hline & $\begin{array}{l}\text { Benchmarking compares innovation processes, management } \\
\text { practices, and standardised metrics with those of other (successful) } \\
\text { organisations. }\end{array}$ \\
\hline \multirow[t]{2}{*}{ Financial architecture } & Investment in innovation \& sourcing of capital. \\
\hline & $\begin{array}{l}\text { Innovation activities are appropriately prioritised and assigned the } \\
\text { necessary financial resources to meet targets and objectives. }\end{array}$ \\
\hline \multirow[t]{6}{*}{ Governance architecture } & Planning \& coordinating the innovation portfolio. \\
\hline & Identifying and planning for key decision points. \\
\hline & $\begin{array}{l}\text { Using fundamental principles to guide innovation process \& make } \\
\text { decisions. }\end{array}$ \\
\hline & $\begin{array}{l}\text { Innovation governance board or committee in place for governing } \\
\text { innovation activities. }\end{array}$ \\
\hline & Establishing intellectual property management \& sharing policy. \\
\hline & $\begin{array}{l}\text { Identifying, documenting, and implementing best-practices for } \\
\text { innovation. }\end{array}$ \\
\hline
\end{tabular}

These requirements can be used in future studies to develop more specific design principles to guide the evaluation and construction of the various sub-architectures of an enterprise.

An example of more detailed design principles for a specific sub-architecture of the enterprise is presented in

Table 2 (for the performance architecture in this case). This is only an example; additional research is required to develop and validate such design principles.

Once such design principles have been defined, they can be used within an enterprise reference architecture to guide the evaluation and design/development of more innovation-capable enterprises by following an enterprise engineering-based approach. Such an approach for changing or improving the architecture or sub-architectures of an enterprise is illustrated in Figure 3. 
Table 2 - Example of more detailed design principles for a specific enterprise sub-architecture

\begin{tabular}{|c|c|c|}
\hline $\begin{array}{l}\text { Enterprise sub- } \\
\text { architecture }\end{array}$ & Innovation capability requirements & Design principles \\
\hline \multirow[t]{5}{*}{$\begin{array}{l}\text { Performance } \\
\text { architecture }\end{array}$} & \multirow[t]{5}{*}{$\begin{array}{l}\text { Innovation metrics have been identified, } \\
\text { defined, and implemented. Targets are aligned } \\
\text { with innovation objectives. Metrics are } \\
\text { monitored to identify process and management } \\
\text { improvements. }\end{array}$} & $\begin{array}{l}\text { Innovation measures monitor the } \\
\text { innovation inputs, outputs, process, } \\
\text { and outcomes. }\end{array}$ \\
\hline & & $\begin{array}{l}\text { Innovation measures are aligned with } \\
\text { the innovation strategy, and adjusted } \\
\text { when necessary. }\end{array}$ \\
\hline & & $\begin{array}{l}\text { The innovation measures are 'rolled- } \\
\text { down' from innovation strategy to } \\
\text { departmental, team, and individual } \\
\text { metrics to guide the appropriate } \\
\text { behaviour. }\end{array}$ \\
\hline & & $\begin{array}{l}\text { Effective systems are used to collect } \\
\text { measures easily and make them visible. }\end{array}$ \\
\hline & & Etc. \\
\hline
\end{tabular}

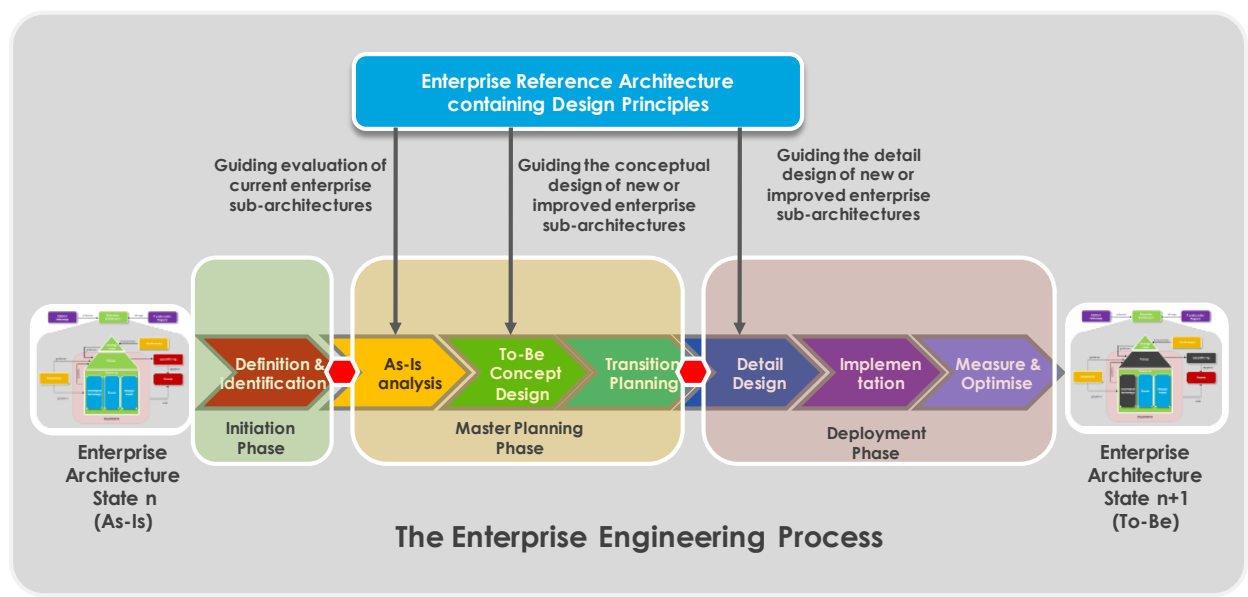

Figure 3: Illustration of where in the enterprise engineering/re-engineering process the enterprise reference architecture containing design principles can be applied.

\section{6}

\section{CONCLUSION}

As is evident from the various definitions of innovation, it is more than simply a novel idea: it is the successful realisation and implementation of that idea. It requires organisations to change. Innovation should therefore be characterised by a process that bridges the invention-to-innovation chasm. By definition, a process requires time, resources, capabilities, knowledge, and structure to be executed and to ensure sound output. Innovation capabilities therefore need to be purposefully 'built into' the DNA of an enterprise; and this requires a structured engineering approach. Just because an organisation has the capability to innovate, this does not imply that it will consistently do so. Innovation capability is a necessary but not sufficient condition. In other words, an organisation must have an innovation capability before it can expect to see regular innovative output; but being capable of innovation does not ensure innovative output. A deep-seated and organisation-wide will, combined with proactive initiatives to innovate, are the catalytic factors that will ensure an innovation-capable organisation.

This research makes a significant contribution by providing a comprehensive and consolidated view from the literature of the requirements for building a more innovation-capable organisation, as well 
as laying the foundation for an enterprise engineering approach to building more innovation-capable enterprises. This was done by identifying various innovation capability requirements from previous studies, and structuring and consolidating these requirements within a comprehensive enterprise architecture framework. This will greatly assist enterprise or business engineers in designing an enterprise architecture and sub-architectures that are capable of sustainable innovation. The proposed framework, with its requirements, will be used in future research studies to develop further generic design principles for the various sub-architectures of an enterprise, thus providing useful guidelines for architecting the enterprise towards an enhanced innovation capability - that is, an organisation with an enhanced capability to innovate successfully and consistently for increased competitiveness. Further research needs to be conducted, however, to validate the impact of such design principles on innovation performance in organisations.

\section{REFERENCES}

[1] Adaptive Inc. 2014. The Adaptive reference model, http://www.adaptive.com/products/adaptiveenterprise-architecture-manager/adaptive-reference-model/

[2] Ahmed, P.K. 1998a. Benchmarking innovation best practice, Benchmarking for Quality Management \& Technology, 5(1), pp. 45-58.

[3] Ahmed, P.K. 1998b. Culture and climate for innovation, European Journal of Innovation Management, 1(1), pp. 30-43.

[4] Alam, S.S,, Arumugam,V,, Nor, N.G.M,, Kaliappan, P, and Fang, L.S. 2013. Relationships between innovation capabilities, business performance, marketing performance and financial performance: A literature review, Business and Management Horizons, 1(1), pp.59-73

[5] Albright, R.E. 2003. Roadmapping convergence. Albright Strategy Group, October 31.

[6] Alves, A.C., Zen, A.C. and Padula, A.D. 2011. Routines, capabilities and innovation in the Brazilian wine industry, Journal of Technology Management and Innovation, 6(2), pp.128-144.

[7] AMICE. 1993. CIMOSA: Open system architecture for CIM, $2^{\text {nd }}$ extended revised version. Berlin: SpringerVerlag.

[8] Assink, M. 2006. Inhibitors of disruptive innovation capability: A conceptual model, European Journal of Innovation Management, 9(2), pp. 215-233.

[9] Baker, K.A. 2002. Management benchmark study, Chapter 14 - Innovation. Office of Planning and Analysis, http://www.au.af.mil/au/awc/awcgate/doe/benchmark.

[10] Bernus, P. 2003. Enterprise models for enterprise architecture and IS09000: 2000, Annual Reviews in Control 27(2), pp.211-220.

[11] Blei, D.M., Ng, A.Y. and Jordan, M.I. 2003. Latent Dirichlet Allocation, Journal of Machine Learning Research, 3, pp. 993-1022.

[12] Blei, D. and Lafferty, J. 2006. Dynamic topic models. Proceedings of the 23rd international conference on Machine learning - ICML '06, pp. 113-120.

[13] Brown, J.S. 2003. Innovating innovation: Foreword to Open innovation by H. Chesbrough, www.johnseelybrown.com/fwd_openinnovation.html.

[14] Camisón, C. and Villar-López, A. 2014. Organisational innovation as an enabler of technological innovation capabilities and firm performance, Journal of Business Research, 67(1), pp.2891-2902.

[15] Carneiro, A. 2000. How does knowledge management influence innovation and competitiveness?, Journal of Knowledge Management, 4(2), pp. 87-98.

[16] Christensen, C.M. and Overdorf, M. 2000. Meeting the challenge of disruptive change, Harvard Business Review, 78(2), pp. 66-76.

[17] Christensen, C.M. and Raynor, M.E. 2003. The innovator's solution - Creating and sustaining successful growth. Boston: Harvard Business School Press.

[18] Anon., n.d. Federal Enterprise Architecture (FEA) | The White House. [Online] Available at: https: / /obamawhitehouse.archives.gov/omb/e-gov/FEA.

[19] Clark, H.C. 1998. Formal knowledge networks. Manitoba, Canada: International Institute for Sustainable Development.

[20] Coetzer, W. 2006. Business, innovation and social networks. Colloquium at the Department of Industrial Engineering, Stellenbosch University.

[21] Cohen, W.M. and Levinthal, D.A. 1990. Absorptive capacity: A new perspective on learning and innovation, Administrative Science Quarterly, 35(1), pp. 128-152.

[22] Cook, C.W. and Hunsaker, P.L. 2001. Management and organisational behavior, $3^{\text {rd }}$ edition. New York: McGraw-Hill.

[23] Cooper, J.R. 1998. A multidimensional approach to the adoption of innovation, Management Decision, 36(8), pp. 493-502.

[24] Cooper, R.G. and Kleinschmidt, E.L. 1996. Winning businesses in product development: The critical success factors, Research Technology Management, 50(3), pp. 18-29, July-August.

[25] Cormican, K. and O'Sullivan, D. 2004. Auditing best practice for effective product innovation management, Technovation, 24, pp. 819-829.

[26] Coulson-Thomas, C. 2001. Unriddling the innovator's dilemma, Strategic Direction, May, pp. 8-10.

[27] Cozijnsen, A.J., Vrakking, W.J. and Van Ijzerloo, M. 2000. Success and failure of 50 innovation projects in Dutch companies, European Journal of Innovation Management, 3(3), pp. 150-159. 
[28] Damanpour, F. 1991. Organizational innovation: A meta-analysis of effects of determinants and moderators, Academy of Management Journal, 34, p. 555-590.

[29] Damanpour, F. 1996. Organizational complexity and innovation: Developing and testing multiple contingency models, Management Science, 42(5), pp. 693-716.

[30] Davila, T., Epstein, M.J. and Shelton, R. 2006. Making innovation work: How to manage it, measure it, and profit from It. Indianapolis: Wharton School Publishing.

[31] Dietz, Jan L.G., Hoogervorst, Jan A.P., Albani, Antonia, Aveiro, David, Babkin, Eduard, Barjis, Joseph, Caetano, Artur, Huysmans, Philip, lijima, Junichi, Kervel, Steven J.H., Van, Mulder, Hans, Op't Land, Martin, Proper, Henderik A., Sanz, Jorge, Terlouw, Linda, Tribolet, José, Verelst, Jan and Winter, Robert. 2013. The discipline of enterprise engineering, International Journal of Organisational Design and Engineering, 3(1), pp. 86-114.

[32] Dismukes, J.P. 2005. Information accelerated radical innovation from principles to an operational methodology, The Industrial Geographer, 3(1), pp.19-42.

[33] DoD AF. 2007. Architecture framework, Version 1.5. Volume I: Definitions and guidelines. DoD Architecture framework Version 1.5.

[34] Donofrio, N. 2004. Innovation: The new reality for national prosperity. $21^{\text {st }}$ century innovation working group recommendations, Version 2.1, Prepared for: The National Innovation Initiative, Available: http://www.compete.org/nii/ .

[35] Doumeingts, G., Vallespir, B., Zanettin, M., and Chen, D. 1992. GIM: GRAI Integrated Methodology. A methodology for designing CIM systems. GRAI/LAP. Universite'Bordeaux 1, version 1.0.

[36] Du Preez, N.D. and Louw, L. 2007. Managing the knowledge supply chain to support innovation. Proceedings: International Conference on Competitive Manufacturing (COMA 07), Feb 07, pp.65-78.

[37] Essmann, H. and du Preez, N.D. 2009. An innovation capability maturity model - Development and initial application, World Academy of Science, Engineering and Technology, 3 (2009-05-23).

[38] Essmann, H.E. 2009. Toward innovation capability maturity. Unpublished PhD thesis. Stellenbosch University, South Africa.

[39] Forsman, H. 2011. Innovation capacity and innovation development in small enterprises: A comparison between the manufacturing and service sectors. Research Policy, 40(5), pp. 739-750.

[40] Größler, A., Grübner, A. and Milling, P.M. 2006. Organisational adaptation processes to external complexity, International Journal of Operations \& Production Management, 26 (3), pp. 254-281.

[41] Guan, B. and Ma, N. 2003. Innovative capability and export performance of Chinese firms, Technovation, 23, 737-747.

[42] Hamel, G. 1996. Strategy as revolution, Harvard Business Review, 74(4), pp. 69-82.

[43] Hamel, G. 2000. Leading the revolution. Boston: Harvard Business School Press.

[44] Hamel, G. 2006. The why, what, and how of management innovation, Harvard Business Review, 84(2), pp. 72-84.

[45] Hargadon, A. and Sutton, R.I. 2000. Building an innovation factory, Harvard Business Review, 78(3), pp. 157-166.

[46] IFIP/IFAC Task Force. 1999. GERAM: Generalized enterprise reference architecture and methodology, Version 1.6.2, Annex to ISO WD15704, IFIP/IFAC Task Force.

[47] Johannessen, J.A., Olsen, B. and Olaisen, J. 1999. Managing and organizing innovation in the knowledge economy, European Journal of Innovation Management, 2(3), pp. 116-128.

[48] Katz, B. 2006. The integration of project management processes with a methodology to manage a radical innovation project. Unpublished Masters thesis in Industrial Engineering, Stellenbosch University, South Africa.

[49] Kimberly, J.R. and Evanisko, M.J. 1981. Organizational innovation: The influence of individual, organizational, and contextual factors on hospital adoption of technological and administrative innovation, Academy of Management Journal, 24, p. 689-713.

[50] Kostoff, R.N., Boylan, B. and Simons, G.R. 2004. Disruptive technology roadmaps, Technological Forecasting \& Social Change, 71, pp. 141-159.

[51] Lankhorst, M.M. 2004. Enterprise architecture modelling - The issue of integration, Advanced Engineering Informatics, Engineering Computing and Technology, 18(4), p. 205.

[52] Lawson, B. and Samson, D. 2001. Developing innovation capability in organizations: A dynamic capabilities approach, International Journal of Innovation Management, 5(3), pp. 377-400.

[53] Leiponen, A. 2006. Managing knowledge for innovation: The case of business-to-business services, Journal of Product Innovation Management, 23, pp. 238-258.

[54] Leseure, M.J., Bauer, J., Birdi, K., Neely, A. and Denyer, D. 2004. Adoption of promising practices: A systematic review of the evidence, International Journal of Management Reviews, 5/6(3 \& 4), pp. 169190.

[55] Liles, D.H., Johnson, M.E. and Meade, L. 1995. The enterprise engineering discipline, Proceedings of the Society for Enterprise Engineering, Orlando.

[56] Louw, L., du Preez. N.D., Essmann, H., Grove, C. and van der Walt, L. 2008. Reference architectures as knowledge management tools guiding and supporting enterprise engineering, in Methods and tools for effective knowledge life-cycle management. Berlin/Heidelberg: Springer-Verlag, pp.391-414.

[57] Maier, M.W., Emery, D. and Hilliard, R. 2001. Software architecture: Introducing IEEE Standard 1471, IEEE Computer, 34(4), pp 107-109.

[58] Martin, J. 1995. The great transition: Using the seven principles of enterprise engineering to align people, technology and strategy. New York: American Management Association. 
[59] Merrifield, D.B. 1999. Innovation management in the $7^{\text {th }}$ great epoch, Research -Technology Management, 42, pp. 10-14.

[60] Stokes, M., 2001. Managing Engineering Knowledge: MOKA: Methodology for Knowledge-based Engineering Applications. London, UK: Professional Engineering Publishing. .

[61] Moore, G.A. 2005. Dealing with Darwin: How great companies innovate at every phase of their evolution. London: Penguin Books.

[62] Neely, A., Filippini, R., Forza, C., Vinelli, A. and Hii. J. 2001. A framework for analysing business performance, firm innovation and related contextual factors: Perceptions of managers and policy makers in two European regions, Integrated Manufacturing Systems, 12(2), pp. 114-124.

[63] O'Connor, G.C. and Ayers, A.D. 2005. Building a radical innovation competency, Research - Technology Management, 48(1), pp.22-31.

[64] Oke, A. 2004. Barriers to innovation management in service companies, Journal of Change Management, 4(1), pp. 31-44.

[65] Op't Land, Martin, Proper, Erik, Waage, Maarten and Cloo, Jeroen. 2009. Enterprise architecture: Creating value by informed governance. Berlin: Springer-Verlag.

[66] Open Group. 2008. The Open Group Architecture Framework (TOGAF), version 8.1.1. Enterprise edition, 2007. http://pubs.opengroup.org/architecture/togaf8-doc/arch/.

[67] Osterwalder, A. and Pigneur, Y. 2010. Business model generation: A handbook for visionaries, game changers, and challengers. Hoboken New Jersey: Wiley.

[68] Patton, K. and Carlsen, A. 1998. Strategies, techniques and tools for knowledge reuse, Internal report. Trondheim, Norway: SINTEF Industrial Management.

[69] Pérez-Bustamante, G. 1999. Knowledge management in agile innovative organizations, Journal of Knowledge Management, 3(1), pp. 6-17.

[70] Phaal, R. 2005. Strategic roadmapping - Linking technology, products and markets for innovation. Unpublished presentation to Henley Management College, University of Cambridge Centre for Technology Management.

[71] Prahalad, C.K. and Hamel, G. 1990. The core competence of the corporation, Harvard Business Review, 68(3), pp. 79-91.

[72] Rebovich, G. 2007. Engineering the enterprise, $1^{\text {st }}$ Annual IEEE Systems Conference, 9-13 April 2007, Honolulu.

[73] Reid, S.E. and de Brentani, U. 2004. The fuzzy front end of new product development for discontinuous innovations: A theoretical model, Journal of Product Innovation Management, 21, pp.170-184.

[74] Rothwell, R. 1992. Successful industrial innovation: Critical factors for the 1990s, R\&D Management, 22(30), pp. 221-239.

[75] Saenz, Oscar A., Chen, Chin-Sheng, Centeno, M. and Giachetti, R.E. 2009. Defining enterprise systems engineering, International Journal of Industrial and Systems Engineering, 4(5), pp. 483-501.

[76] Salvendy, G. 1992. Handbook of industrial engineering. Canada: John Wiley \& Sons.

[77] Schekkerman, J. 2003. How to survive in the jungle of enterprise architecture frameworks. Victoria, BC: Trafford Publishing.

[78] Schneider, B., Brief, A.P. and Guzzo, R.A. 1996. Creating a climate and culture for sustainable change, Organisational Dynamics, 24(4), pp. 7-19.

[79] Schumpeter, J.A. 1939. Business cycles: A theoretical, historical and statistical analysis of the capitalistic process. New York: McGraw-Hill.

[80] Schutte, C.S.L. and du Preez, N.D. 2008. Knowledge networks for managing innovation projects. PICMET 2008 International Conference Proceedings, 27-31 July, Cape Town, South Africa.

[81] Sowa, J. and Zachman, J. 1992. Extending and formalizing the framework for information-systems architecture, IBM Systems Journal, 31(3), pp. 590 - 616.

[82] Spewak, S. 1993. Enterprise architecture planning: Developing a blueprint for data, applications, and technology. New York: Wiley.

[83] Stopper, J.M. 2002. Roadmapping continuous innovation. The Learning Trust, http://www.learningtrust.com.

[84] Teece, D.J. 2007. Explicating dynamic capabilities: The nature and microfoundations of sustainable enterprise performance, Strategic Management Journal, 28(13), pp. 1319-1350.

[85] Teece, D.J. 2010. Business models, business strategy and innovation, Long Range Planning, 43, pp. 172 194.

[86] Teece, D.J., Pisano, G. and Shuan, A. 1997. Dynamic capabilities and strategic management, Strategic Management Journal, 18(7), pp. 509-33.

[87] Terziovski, M. 2007. Building innovation capability in organizations: An international cross-case perspective. London: Imperial College Press.

[88] Tidd, J, and Bessant, J,R. 2009. Managing innovation: Integrating technological, market and organisational change, $4^{\text {th }}$ edition. London: John Wiley \& Sons.

[89] Utterback, J.M. 1986. Innovation and corporate strategy, International Journal of Technology Management, 1 (1-2), pp.119-131.

[90] Vernadat, F.B. 1996. Enterprise modeling and integration: Principles and applications. London: Chapman \& Hall.

[91] Wan, D., Ong, C.H. and Lee, F. 2005. Determinants of firm innovation in Singapore, Technovation, 25, pp. 261-268.

[92] Wang, C.-H., Lu, I.-Y. and Chen, C.-B. 2008. Evaluating firm technological innovation capability under uncertainty, Technovation, 28(6), pp.349-363. 
[93] Weinberg, G.M. 2001. An introduction to general systems thinking. New York: Dorset House Publishing.

[94] Williams, T. 2005. Assessing and moving on from the dominant project management discourse in the light of project overruns, IEEE Transactions on Engineering Management, 52(4), pp. 497 - 508.

[95] Williams, T.J., Rathwell, G.A. and Li, H. 1996. A handbook on master planning and implementation for enterprise integration programmes. Report n8 160. W. Lafayette: Purdue Laboratory for Applied Industrial Control, Purdue University.

[96] Wind, Y. and Crook, C. 2005. The power of impossible thinking. Upper Saddle River, New Jersey: Wharton School Publishing.

[97] Wycoff, J. 2003. Innovation tools, www.innovationtools.com.

[98] Yam, R., Lo, W., Tang, E. and Lau, A. 2011. Analysis of sources of innovation, technological innovation capabilities, and performance: An empirical study of Hong Kong manufacturing industries, Research Policy, 40(3), pp.737-747.

[99] Zachman J.A. 1987. A framework for information systems architecture, IBM Systems Journal, 26(3), pp.276-292.

[100] Zairi, M. 1995. Benchmarking innovation for best practice, World Class Design to Manufacture, 2(3), pp. 33-40.

[101] Zawislak, P.A., Alves, A.C., Tello-Gamarra, J., Barbieux, D. and Reichert, F.M. 2012. Innovation capability: From technology development to transaction capability, Journal of Technology Management \& Innovation, 7(2), pp. 14-27. 